\title{
BCR-ABL Peptide Vaccine
}

National Cancer Institute

\section{Source}

National Cancer Institute. BCR-ABL Peptide Vaccine. NCI Thesaurus. Code C2205.

A multivalent antineoplastic vaccine comprised of the bcr-abl oncogene breakpoint fusion peptide that elicits a bcr-abl specific $\mathrm{T}$-cell immune response. ( $\mathrm{NCl04)}$ 